УДК 657

\title{
КОНЦЕПЦІї ЗБЛИЖЕННЯ СИСТЕМ БУХГАЛТЕРСЬКОГО ОБЛІКУ ТА ФІНАНСОВОГО ЗВІТУВАННЯ
}

\section{CONCEPTS OF APPROXIMATION OF ACCOUNTING AND FINANCIAL REPORTING SYSTEMS}

\author{
Шушакова Ірина Костянтинівна \\ кандидат економічних наук, старший викладач, \\ Київський національний торговельно-економічний університет \\ ORCID: https://orcid.org/0000-0002-3811-683X \\ Зябченкова Ганна Василівна \\ старший викладач, \\ Київський національний торговельно-економічний університет \\ ORCID: https://orcid.org/0000-0003-2417-0154 \\ Кузуб Михайло Віталійович \\ старший викладач, \\ Київський національний торговельно-економічний університет \\ ORCID: https://orcid.org/0000-0001-6222-4892
}

\author{
Shushakova Iryna, Ziabchenkova Ganna, Kuzub Mykhailo \\ Kyiv National University of Trade and Economics
}

\begin{abstract}
Інтеграція України у Європейське співтовариство вимагає від українських підприємств впровадження змін у сфрері управління компаніями. Одним з основних складових, що характеризує підприємство та є важливим для користувачів, $є$ зрозуміла звітність. Представлення звітності за Міжнародними стандартами фрінансової звітності (далі - МСФЗ) не є обов'язковим для всіх компаній, але звітність у такій фрормі дедалі частіше хочуть бачити потенційні іноземні інвестори або банки чи інші фрінансові установи при наданні кредитів. Гармонізація бухгалтерського обліку та фрінансової звітності суб'єктів господарювання тісно пов'язана з глобалізацією економічних процесів та економіки у світовому масштабі. Фінансова звітність є структурованим відображенням фрінансового стану та фрінансових результатів діяльності суб'єкта господарювання. Оптимальним напрямом розвитку національної системи обліку та фрінансової звітності, враховуючи світовий досвід, є її гармонізація 3 МСФЗ, тобто наближення систем, а не повна їх імплементація.
\end{abstract}

Ключові слова: Міжнародні стандарти фрінансової звітності (МСФЗ), Національні положення (стандарти) бухгалтерського обліку (НПСБО), фрінансова звітність, консолідована фрінансова звітність, конвергенція.

Интеграция Украины в Европейское сообщество требует от украинских предприятий внедрения изменений в сорере управления компаниями. Одним из основных составляющих, характеризует предприятие и является важным для пользователей, есть понятная отчетность. Представление отчетности по Международным стандартам фринансовой отчетности (далее - МСФО) не является обязательным для всех компаний, но отчетность в такой форме все чаще хотят видеть потенциальные иностранные инвесторы, банки или другие фринансовые учреждения при предоставлении кредитов. Гармонизация бухгалтерского учета и фринансовой отчетности субъектов хозяйствования тесно связана с глобализацией экономических процессов и экономики в мировом масштабе. Финансовая отчетность является структурированным отображением фринансового состояния и фринансовых результатов деятельности предприятия. Оптимальным направлением развития национальной системы учета и финансовой отчетности, учитывая мировой опыт, является ее гармонизация с МСФО, то есть приближение систем, а не полная их имплементация.

Ключевые слова: Международные стандарты фринансовой отчетности (МСФО), Национальные положения (стандарты) бухгалтерского учета (НПСБУ), фринансовая отчетность, консолидированная фринансовая отчетность, конвергенция.

Ukraine's integration into the European Community requires Ukrainian companies to implement changes in the field of corporate governance. One of the main components that characterizes the company and is important for 
users is clear reporting. Reporting under International Financial Reporting Standards (IFRS) is not mandatory for all companies, but reporting in this form is increasingly seen by potential foreign investors or banks or other financial institutions when lending. The harmonization of accounting and financial reporting of economic entities is closely linked to the globalization of economic processes and the global economy. Financial statements are a structured reflection of the financial position and financial performance of an entity. The optimal direction of development of the national system of accounting and financial reporting, taking into account the world experience, is its harmonization with IFRS, ie approximation of systems, instead of their full implementation. The purpose of the article is to study the concepts of convergence of accounting and financial reporting systems according to NAS and IFRS. The constituent elements of international accounting and financial reporting standards are summarized. The benefits of IFRS are identified. The topical issues of application of IFRS in Ukraine due to the imperfection of the transformation of financial statements to the requirements of IFRS, which leads to a number of technical nuances associated with their application. The companies that are required to apply IFRS are described. The processes of harmonization, standardization and convergence of IFRS are studied. It is established that in order to transition to international standards of accounting and financial reporting, enterprises need to go through a long way of adaptation and fully harmonize their work in accordance with international standards. As previously noted, painstaking work is being done in this direction. Businesses should clearly understand that the main condition for their effective management, attraction of investment resources is the reflection of the accounting system of reliable and complete information that users want to explore.

Keywords: International Financial Reporting Standards (IFRS), National Accounting Standards, financial statements, consolidated financial statements, convergence.

Постановка проблеми. Інтеграція України у Європейське співтовариство вимагає від українських підприємств впровадження змін у ссрері управління компаніями. Одним з основних складових, що характеризує підприємство та $є$ важливим для користувачів, $€$ зрозуміла звітність. Представлення звітності за Міжнародними стандартами фрінансової звітності (далі - МСФЗ) не $€$ обов'язковим для всіх компаній, але звітність у такій формі дедалі частіше хочуть бачити потенційні іноземні інвестори або банки чи інші фрінансові установи при наданні кредитів. Для вирішення зазначених проблем фрінансову звітність, як основу інсормаційного забезпечення прийняття рішень, необхідно розвивати у напрямі покращення механізму інорормаційного обміну між зацікавленими користувачами та підприємством. Для країн, які прагнуть завоювати міжнародні ринки і $є$ зацікавленими в іноземному капіталі, першочергового значення набувають питання дослідження системи норм, принципів, правил і засобів надання фрінансової інфрормації за допомогою бухгалтерського обліку, яка була б зрозумілою для іноземних інвесторів і кредиторів.

Аналіз останніх досліджень і публікацій. Міжнародні стандарти бухгалтерського обліку - це система принципів, методів та процедур ведення бухгалтерського обліку, що визначає основи подання фрінансової звітності загального призначення для забезпечення їхньої зі ставності 3 фрінансовою звітністю суб'єкта господарювання за попередні періоди, а також із фрінансовою звітністю інших суб'єктів господарювання. Найбільш ґрунтовно свої позиції щодо впровадження міжна- родних стандартів висвітлювали у своїх працях Васильєва В.Г., Жука В.М., Кірейцева Г.Г., Коцупатрого М.М., Костюченко К.С., Голов С.Ф., Тітаренко Г.Б., Світлична В.Ю., Малик С.М., Лапішко М.Л., Хілл Б. та інші дослідники.

Питанням гармонізації обліку національних стандартів із міжнародними займалися Ф. Бутинець, В. Качалін, С. Голов, В. Костюченко, І. Бланк, В. Швець, Я. Соколов. Запровадження національних П(С)БО в підприємствах України на засадах, що не суперечать МСБО, та подальше затвердження цього у Законі «Про бухгалтерський облік і фрінансову звітність в Україні» наблизило методику ведення обліку до міжнародних вимог, однак це призвело до виникнення ряду моментів, які ставлять під сумнів обґрунтованість звітної інфрормації.

Мета дослідження. Метою статті $€$ дослідження концепцій зближення систем бухгалтерського обліку та фрінансового звітування за НПСБО та МСФЗ.

Виклад основного матеріалу дослідження. Міжнародні стандарти фрінансової звітності (МСФЗ) являють собою найбільш універсальну систему обліку на сьогодні, яка $€$ зрозумілою та доступною для сприйняття користувачами різних країн світу. Впровадження МСФЗ дозволяє почергово усунути недоліки та невідповідності вітчизняної системи бухгалтерського обліку без порушення її цілісності.

Рада зі стандартів фрінансового обліку (FASB) зауважує, що головна мета обліку забезпечення інформацією, яка $€$ корисною для раціонального інвестування, кредитування й інших подібних рішень [1]. 
За даними бухгалтерського обліку складається фрінансова звітність, що є завершальним етапом облікового процесу.

Фінансовою звітністю слід вважати систему узагальнених показників, ссрормованих на підставі даних рахунків бухгалтерського обліку та іншої релевантної фрінансової інсрормації про суб'єкт господарювання за звітний період, призначеної для широкого кола користувачів з метою здійснення управління та прийняття економічних рішень.

Фінансова звітність відображає узагальнені показники бухгалтерського обліку та включає іншу релевантну інорормацію: відомості про галузь; види діяльності; опис концептуальних засад і принципів облікової політики господарюючого суб'єкта; судження керівництва про фрактичні та потенційні події та їхні наслідки; широке коло аналітичних показників (звітність за сегментами, коефріцієнти співвідношення ціни акції та прибутку на одну акції і т.д.). Систематизовані дані бухгалтерського обліку - основа для складання усіх видів звітності суб'єкта господарювання.

Під бухгалтерською звітністю варто розуміти систему узагальнених показників, сорормованих відповідно до нормативних документів, що регулюють бухгалтерський облік, та на підставі даних рахунків бухгалтерського обліку з обов'язковим дотриманням балансового узагальнення інфрормації для здійснення управління економічним суб'єктом [2].

Розглядаючи зв'язок між бухгалтерською та фрінансовою звітністю, важливо ідентисрікувати десрініції «фрінансова звітність», «фрінансове звітування» та «фрінансові звіти».

У статті Ю. Івахіва зауважено, що термін «financial reporting» варто перекладати як «фрінансове звітування», під яким науковець розуміє процес розкриття широкого спектру корисної для користувачів інформації про підприємство, додаткових відомостей про особливості організації та ведення його господарської діяльності, добровільного висловлювання керівництва щодо очікуваних перспектив, потенційних можливостей і ризиків [3].

Поняття «фрінансова звітність» («financial statement») слід використовувати для позначення інорормаційного продукту, порядок формування й поширення якого визначається обліковими стандартами.

Термін «фрінансові звіти» («financial statements») - сукупність звітних фрорм, в яких наводиться інорормація про підприємство / групу підприємств у вартісному вимірі та поря- док фрормування якої визначено стандартами бухгалтерського обліку і фрінансової звітності.

Зауважимо, що чинна нормативно-правова база України, зокрема стаття 12 Закону України «Про бухгалтерський облік та фрінансову звітність в Україні» та Національні положення (стандарти) бухгалтерського обліку (далі НП(С)БО), регулюють складання та подання фрінансових звітів підприємства, які включають: баланс (звіт про фрінансовий стан), звіт про фрінансові результати (звіт про сукупний дохід), звіт про рух грошових коштів, звіт про власний капітал та примітки до фрінансових звітів.

НПСБО - нормативно-правовий акт, затверджений Міністерством фрінансів України, що визначає принципи та методи ведення бухгалтерського обліку і складання фрінансової звітності, що не суперечать міжнародним стандартам (МСФ3) [4].

Міжнародна система бухгалтерського обліку (далі - МСБО) - система принципів, методів та процедур ведення бухгалтерського обліку і складання фрінансової звітності [5].

МСФЗ - це цілісна, постійно вдосконалювана система обліку та фрінансової звітності, що узагальнює принципи і правила складання фрінансових звітів, яка виникла в результаті посилення процесів економічної інтеграції країн і спрямована на зближення методології обліку та звітності в різних країнах світу [6].

Міжнародні стандарти бухгалтерського обліку та фрінансової звітності містять такі складники (рис. 1).

Розглядаючи позитивні сторони використання МСФЗ, розділяємо думку багатьох науковців, які схиляються до того, що максимальне зближення національних стандартів фрінансової звітності з міжнародними сьогодні $€$ одним 3 першочергових завдань, що зумовлено основними перевагами МСФЗ (рис. 2).

Підтримуємо думку авторів статті [6], в якій зазначено, що адаптація звітності українських підприємств до МСФЗ надасть змогу: уникнути необхідності в складанні податкової й спеціалізованої звітності; зменшити ризики для інвесторів та кредиторі; забезпечити прозорість і зрозумілість інорормації; підвищити зростання довіри до показників фрінансової звітності; поглибити міжнародну кооперацію у галузі бухгалтерського обліку; зменшити витрати на розроблення власних стандартів.

Оскільки МСФЗ застосовуються вітчизняними підприємствами не повною мірою, окреслимо низку недоліків вітчизняної фрінансової звітності (рис. 3). 


\section{Складники міжнародних стандартів бухгалтерського} обліку та фінансової звітності

Концептуальна основа фінансової звітності (документ, який описує загальні вимоги до якісних характеристик фінансової інформації та основні облікові концепції, що дозволяють скласти звітність МСФЗ)

17 Міжнародних стандартів фінансової звітності (МСФЗ, англ. - IFRS)

25 діючих Міжнародних стандартів бухгалтерського обліку

МСФ3 для малих та середніх підприємств (IFRS for SMEs)

Інтерпретації (роз'яснення) (нові IFRIC (Міжнародний комітет з інтерпретації фінансової звітності) і старі SIC (Постійний комітет з інтерпретацій))

Рис. 1. Узагальнення складників міжнародних стандартів бухгалтерського обліку та фрінансової звітності

Джерело: побудовано на основі [4]

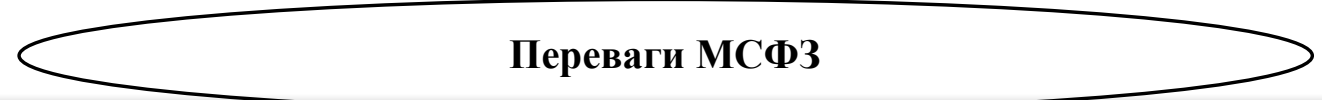

Характеризуються чіткою економічною логікою та узагальнюють у собі світову практику складання фінансової звітності

Інформація дозволяє користувачам аналізувати наслідки прийняття рішень, здійснювати прогнозування майбутнього розвитку та виступає основою прийняття стратегічних

Показники у звітності характеризуються співставністю, що обумовлює підвищення інвестиційної привабливості таких підприємств

Містить не лише показники господарської діяльності підприємства, а й характеристики здійснюваних процесів, які відображають як масштаби, так і якість такої господарської діяльності

Інформація є доступною для широкого кола споживачів

Рис. 2. Переваги МСФ3

Джерело: побудовано на основі [5; 7] 


Недоліки вітчизняної фінансової звітності
$\begin{gathered}\text { Недостатньо об'єктивне представлення інформації (причиною здебільшого є суб'єктивізм осіб, } \\ \text { якладають фінансову звітність, через що звітність містить інформацію, яка вигідна для } \\ \text { власників) }\end{gathered}$
$\begin{gathered}\text { Уніфікований обов'язковий формат подання фінансової звітності (регламентуєтся державою, практично } \\ \text { мінімізує можливість здійснення агрегування показників фінансової звітності та їх згортання) }\end{gathered}$
$\begin{gathered}\text { Зміст фінансової звітності у відповідності з вимогами вітчизняного законодавства не надає повного } \\ \text { обсягу інформації за ключовими фінансовими та нефінансовими показниками діяльності підприємств }\end{gathered}$
$\begin{gathered}\text { Непередбачливість, неузгодженість, суперечливість правового регулювання фінансової звітності } \\ \text { во Україні }\end{gathered}$
основний орієнтир вітчизняної фінансової звітності спрямовано на надання інформації для
допомогу аналітику, ії користувачами виступають інвестори, кредитори, менеджери

Рис. 3. Основні недоліки вітчизняної фінансової звітності

Джерело: побудовано на основі [5; 8; 9]

Існують проблеми застосування МСФЗ на теренах вітчизняної економіки через недосконалість трансфоормації фрінансової звітності до вимог МСФЗ (брак висококваліфікованих профресіоналів з МСФ3 (перекладачів, викладачів, аудиторів 3 головними бухгалтерами, податківців) призводить до ряду технічних проблем, пов'язаних з їхнім застосуванням; брак фрінансування; ускладнена процедура оприлюднення тощо).

Проте водночас варто зазначити, що на сьогодні здійснено великі кроки щодо переходу на міжнародну фрінансову звітність.

Так, у березні 2014 р. була підписана Угода про асоціацію між Україною й Європейським Союзом [10], згідно з якою наша держава взяла на себе певні зобов'язання, зокрема щодо гармо- нізації законодавства, яке здійснює регулювання підприємницької діяльності. Статтею 387 Угоди передбачено ресормування бухгалтерського обліку й аудиту 3 переходом на міжнародні стандарти. Зауважимо, що вимоги, зазначені у Додатку XXXV до Угоди, сприяли прийняттю нової редакції Закону України «Про бухгалтерський облік та фрінансову звітність в Україні» [11] та Закону України «Про аудит фрінансової звітності та аудиторську діяльність» [12].

Згідно статті 12 Закону України «Про бухгалтерський облік та фрінансову звітність в Україні» та Постанови Кабінету Міністрів України «Про внесення змін до Порядку подання фрінансової звітності» 31 січня 2018 р. оновлено критерії підприємств, які зобов'язані готувати фрінансову звітність за МСФЗ (рис. 4). 


\section{Підприсмства, які зобов'язані застосовувати МСФ3}

\section{Публічні акціонерні товариства}

\section{Підприсмства - емітенти цінних паперів.}

Якщо їхні цінні папери допущені до торгів на фондових біржах або щодо них здійснено публічну пропозицію

\begin{tabular}{|c|}
\hline Банки \\
\hline Страховики \\
\hline Кредитні спілки \\
\hline \hline
\end{tabular}

\section{Підприємства, які здійснюють діяльність 3 видобутку корисних копалин загальнодержавного значення.}

Перелік корисних копалин загальнодержавного значення затверджений постановою КМУ від 12.12.94 р. № 827. Міськводоканали не зобов'язані переходити на МСФЗ: хоча підземні та поверхневі води є у переліку корисних копалин загальнодержавного значення, відбір води не вважається видобутком)

Підприсмства, які провадять господарську діяльність за окремими видами фінансової діяльності. Види такої діяльності за КВЕД ДК 009:2010: недержавне пенсійне забезпечення (група 65.3); надання інших фінансових послуг (розділ 64); допоміжна діяльність у сферах фінансових послуг (розділ 66, крім підрозділу 66.2)

\section{Великі підприсмства}

Незалежно від сфери діяльності відповідають щонайменше двом критеріям з таких: балансова вартість активів - понад 20 млн євро; чистий дохід від реалізації - понад 40 млн євро; середня кількість працівників - понад 250 осіб (рис. 5)

\section{Рис. 4. Підприємства, які зобов'язані застосовувати МСФЗ}

Джерело: побудовано на основі [11; 13]

Вищезазначені підприємства також зобов'язані готувати консолідовану фрінансову звітність, якщо вони контролюють інші підприємства відповідно до статті 12 Закону України «Про бухгалтерський облік та фрінансову звітність в Україні» та МСФЗ 10 «Консолідована фрінансова звітність» [13].

Підприємства, які не підпадають під дані критерії, мають право вести облік і готувати фрінансову звітність за національними положеннями (стандартами) бухгалтерського обліку чи добровільно перейти на використання міжнародних стандартів.

Підприємства, які складають фрінансову звітність за МСФЗ, зобов'язані здійснювати ведення бухгалтерського обліку згідно з обліковою політикою за МСФЗ після подання першої фрінансової звітності за міжнародними стандартами.

31 січня 2019 р. набрали чинності зміни до Закону України «Про бухгалтерський облік та фрінансову звітність в Україні». Тобто компанії, які визначено суспільно значущими, мають в обов'язковому порядку перейти на міжнародні стандарти фрінансової звітності.

В умовах сьогодення гостро постало питання наближення системи бухгалтерського обліку та фрінансового звітування. Тому широко досліджуються проблеми стандарти- 


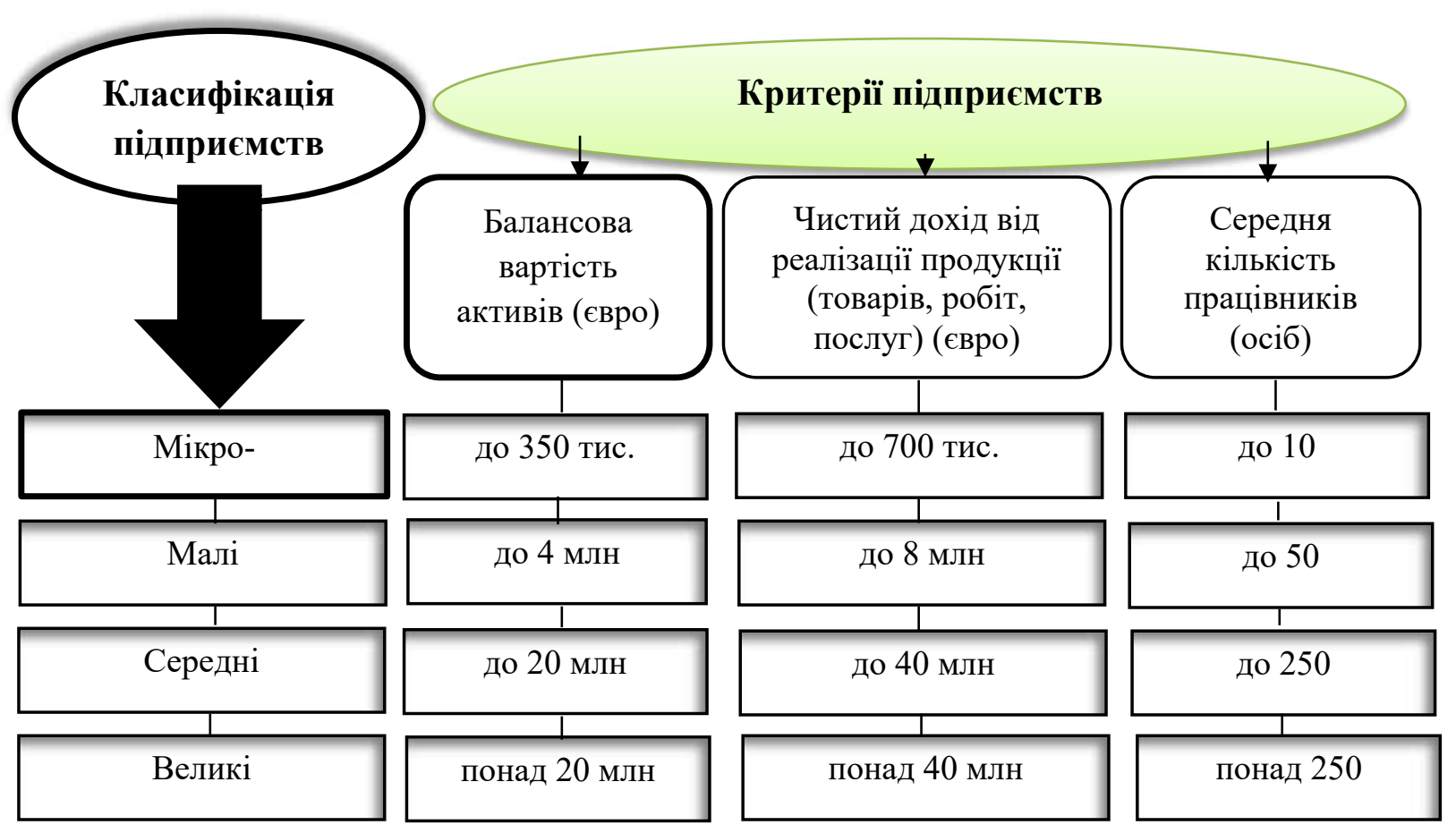

Рис. 5. Критерії визначення розміру підприємств

Джерело: побудовано на основі [11]

зації, гармонізації обліку національних облікових систем до міжнародних стандартів і норм, а також конвергенції. Проблеми є досить актуальними, оскільки на процес узгодження та гармонізації бухгалтерського обліку на вітчизняних підприємствах у відповідності до МСБО має бути максимально пришвидшеним через посилення євроінтеграційних прагнень.

Якщо розглядати міжнародний рівень, то гармонізація фрінансової звітності значить, що фрінансова звітність окремої країни має відповідати вимогам МСФЗ. Це тривалий і трудомісткий процес.

Гармонізація фрінансової звітності на локальному рівні передбачатиме, що фрінансова звітність у країні, яка входить в континентальну групу, має відповідати вимогам стандартів обліку країн певного континенту. Країни $€ С$ мають власні директиви з обліку й аудиту та вимоги по гармонізації фрінансової звітності.

Стандартизація бухгалтерського обліку трактується як процес розроблення та послідовного використання єдиних вимог, правил і принципів для визнання, оцінки та відображення в фрінансових звітах окремих об'єктів бухгалтерського обліку; застосування уніфрікованого набору стандартів, які регулюють облікову подію та її відображення в звітності.

Стандартизація надає змогу глобалізувати: облікову політику, принципи і системи бухгалтерського обліку та звітності; здійснюється в межах унісрікації обліку на міжнародному рівні, яку здійснює Комітет із міжнародних стандартів бухгалтерського обліку [14].

Згідно зі стандартами фрінансової звітності, десрініція «конвергенція» має два значення: 1) зусилля, які вживаються органами стандартизації фрінансової звітності у світі задля усунення відмінностей в стандартах фрінансової звітності у різних країнах; 2) відсутність відмінностей в стандартах фрінансової звітності між країнами. Отож, конвергенція виступає як процес і як мета.

Висновки. Зауважимо, що конвергенція стандартів фрінансової звітності, за основу для якої обрано МСФЗ, триває, але, нез'ясованою $\epsilon$ ії якість. Існують побоювання, що конвергенція перетворилася на приєднання.

Необхідно уникнути спроб перевести облік в Україні на пакетну конвергенцію, тому слід не тільки розмірковувати, але й брати активну участь в розробці стандартів, акцентуючи увагу на зауваженнях щодо дискусійних документів і проектів.

Загалом, для переходу на міжнародні стандарти бухгалтерського обліку та фрінансової звітності, підприємствам необхідно пройти ще тривалий шлях адаптації та в повній мірі гармонізувати свою роботу згідно 3 міжнародними нормами. Як було зауважено попе- 
редньо, в даному напрямі ведеться клопітка робота. Суб'єкти господарювання мають чітко усвідомити, що головною умовою їхнього ефрективного господарювання, залучення інвестиційних ресурсів $є$ відображення системою бухгалтерського обліку достовірної та повної інформації, яку бажають дослідити користувачі.

\section{СПИСОК ВИКОРИСТАНИХ ДЖЕРЕЛ:}

1. Костюченко В. Травневий конгрес у Парижі. Бухгалтерський облік і аудит. 2013. № 6. С. 54-55.

2. Озеран А. В. Гармонізація фрінансової звітності підприємств з міжнародними стандартами та потребами управління : дис. ... д-ра екон. наук : 08.00.09. Київський національний економічний університет імені Вадима Гетьмана. Київ, 2015. С. 559.

3. Івахів Ю. Фінансове звітування як система розкриття інформації. Економіка. 2011. № 5(112). С. 37-42.

4. Міжнародні стандарти фрінансової звітності. Офріційний сайт Міністерства фрінансів України. URL: https://www.mof.gov.ua/uk/mizhnarodni-standarti-finansovoi-zvitnosti

5. Рєзнікова В. В., Орлова О. С. Напрями гармонізації бухгалтерського обліку та фрінансової звітності суб'єктів господарювання в Україні. Університетські наукові записки. 2014. № 2(50). С. $210-224$.

6. Колінько Н. І., Єзерська Т. Є. Відповідність фрінансової звітності українських підприємств міжнародним стандартам. Науковий вісник НЛтУ України. 2012. Вип. 22.4. С. 215-220.

7. Олійник О. Міжнародні стандарти бухгалтерського обліку. Чернівці : Українська консалтингова мережа, 2007. 56 c.

8. Муравський В. В. Організаційні аспекти фрормування і подання фрінансової звітності під впливом інфрормаційної технології гіпертексту. Вісник Житомирського державного технологічного університету. 2009. № 1. С. 190-193.

9. Штулер Г. Г. Перспективні напрямки узгодження фрінансової звітності в Україні з міжнародними стандартами. Науковий вісник Ужгородського університету. Економіка. 2010. Вип. 29. Ч. 2. С. 253-256.

10. Угода про асоціацію між Україною та Європейським Союзом від 30.11.2015 № 72/14-612/1-2980. URL: https://zakon.rada.gov.ua/laws/show/984_011

11. Про бухгалтерський облік та фрінансову звітність в Україні : Закон України від 16.07.1999 № 996-XIV. URL: https://zakon.rada.gov.ua/laws/show/996-14

12. Про аудит фрінансової звітності та аудиторську діяльність : Закон України 21.12.2017 № 2258-VIII. URL: https://zakon.rada.gov.ua/laws/show/2258-viii

13. Острікова Т., Рогозний С., Шевцова Т. Національні особливості переходу на МСФЗ та їх вплив на оподаткування. Податки\&Бухоблік. 2018. № 77. URL: https://i.factor.ua/ukr/journals/nibu/2018/september/issue-77/ article-39538.html

14. Рожелюк В. М. Стандартизація та гармонізація обліку в контексті міжнародних та національних стандартів. Інноваційна економіка. 2011. № 4(23). С. 118-122.

\section{REFERENCES:}

1. Kostyuchenko V. (2013) May Congress in Paris. Accounting and auditing, no. 6, pp. 54-55.

2. Ozeran A.V. (2015) Harmonization of financial reporting of enterprises with international standards and management needs: dis. ... dr. econ. science: 08.00.09. Vadym Hetman Kyiv National University of Economics. Kyiv, p. 559.

3. Ivakhiv Y. (2011) Financial reporting as a system of information disclosure. Economy, no. 5(112), pp. 37-42.

4. International Financial Reporting Standards. Official site of the Ministry of Finance of Ukraine. Available at: https://www.mof.gov.ua/en/mizhnarodni-standarti-finansovoi-zvitnosti

5. Reznikova V.V., Orlova O.S. (2014) Directions of harmonization of accounting and financial reporting of business entities in Ukraine. University scientific notes, no. 2(50), pp. 210-224.

6. Kolinko N.I., Yezerska T.E. (2012) Compliance of financial statements of Ukrainian enterprises with international standards. Scientific Bulletin of NLTU of Ukraine, no. 22.4, pp. 215-220.

7. Oliynyk O. (2007) International accounting standards. Chernivtsi: Ukrainian Consulting Network, 56 p.

8. Muravsky V.V. (2009) Organizational aspects of formation and presentation of financial statements under the influence of hypertext information technology. Bulletin of Zhytomyr State Technological University, no. 1, pp. 190-193.

9. Shtuler G.G. (2010) Perspective directions of harmonization of the financial reporting in Ukraine with the international standards. Scientific Bulletin of Uzhhorod University. Economy, no. 29(2), pp. 253-256. 
10. Association Agreement between Ukraine and the European Union dated 30.11.2015 № 72/14-612/1-2980. Available at: https://zakon.rada.gov.ua/laws/show/984_011

11. On accounting and financial reporting in Ukraine: Law of Ukraine of 16.07.1999 № 996-XIV. Available at: https://zakon.rada.gov.ua/laws/show/996-14

12. On audit of financial statements and auditing activities: Law of Ukraine 21.12.2017 № 2258-VIII. Available at: https://zakon.rada.gov.ua/laws/show/2258-viii

13. Ostrikova T., Rogozny S., Shevtsova T. (2018) National features of the transition to IFRS and their impact on taxation. Taxes\&Accounting, no. 77. Available at: https://i.factor.ua/eng/journals/nibu/2018/september/issue-77/ article-39538.html

14. Rozhelyuk V.M. (2011) Standardization and harmonization of accounting in the context of international and national standards. Innovative economy, no. 4(23), pp. 118-122. 